\title{
Indigenous Goat Selection and Breeding Practices in Pastoral areas of West Guji zone, Southern Oromia, Ethiopia
}

Teshager Muluneh ( $\sim$ teshagermuluneh2005@gmail.com )

Injibara University

Wondim Awoke

Injibara University

\section{Research Article}

Keywords: Breeding, Castration, Indigenous, Selection

Posted Date: December 28th, 2021

DOI: https://doi.org/10.21203/rs.3.rs-1194530/v1

License: (a) (1) This work is licensed under a Creative Commons Attribution 4.0 International License.

Read Full License 


\section{Abstract}

Placing relevant breeding objectives and identification of indigenous breeding practices is crucial to integrating modern development in animal breeding into purposeful industry programs. Hence, the objective of this study was to identify selection criteria and indigenous breeding practices of the goat in Abaya and Galan district southern Oromia, part of Ethiopia. Data were collected from 180 households through interview schedules and focus group discussions. The effective population size and inbreeding rate of the community were calculated using $\Delta \mathrm{F}=1 / 2 \mathrm{Ne}$. Conformation, growth rate, coat color for buck and conformation, twining ability, age at sexual maturity, kidding interval, and color for females are selection criteria for replacement of stock in the study area. In both districts, farmers have relatively similar production and breeding objectives. Conformation is hub selection criteria for replacement of breeding flock. The study area has liable by inbreeding 0.22 in Abaya and 0.29 in Galan. Goat in the study area is prolific twinning birth (72.22\%). Trait preferences of farmers in goats were conformation, growth rate, twinning, and kidding interval. Hence adopting a community-based goat breeding program that is suited to study areas which aimed at improving preferred traits is relevant.

\section{Introduction}

According to Kosgey et al. (2008), small ruminants are an integral part of livestock keeping in SubSaharan Africa that supports a regular large human population for both tangible and/or intangible purposes. Small ruminants provide income, meat, milk, skin, manure, serve as a living bank against the various climatic challenges (crop failure, drought, and flooding), and have served for socio-cultural values for diverse traditional communities (Adane and Girma, 2008).

Ethiopia is home to varied goat populations, numbering 30.20 million heads, out of these total goat populations $70.61 \%$ are females and the remained are males (CSA, 2017). In Ethiopia, goat production has traditionally been an integral part of the farming activities in all agro-climatic conditions (Dereje et al., 2013). Being relatively tolerant to drought, more than $75 \%$ of the goat population is found in large flocks in the arid and semi-arid lowlands (Gebreyesus et al., 2012; Solomon et al., 2010).

The process of genetic improvement of livestock is systematic and follows several important steps: identification of the breeds or strains of livestock and type of the environment in which they reared selection of breeding objectives, development of selection criteria, genetic evaluation, and finally design of appropriate breeding systems (Mekasha and Isaac, 2004). Genetic improvement will be accompanied by a good understanding of the different farming systems and when simultaneously addressing several constraints (Kosgey and Isaac, 2004). For successful goat improvement programs, the compatibility of the genotypes with those of the breeding objectives of the communities and the production system is indispensable (Belete et al., 2015). Farmers' preferred traits level in the animals may be an indirect indication of what constitutes a good animal, the successful pursuit of which constitutes good achievements of the breeding objectives (Gemeda, 2010). 
Breeding objective defines the direction in which farmers would like to go towards satisfying their demand for specific products and services from the animals and increasing profit (Nandolo et al., 2016). Breeding objectives include all relevant characteristics of an animal such as production, reproduction, fitness, and health characteristics (Kosgey and Isaac, 2004). Breeding objective traits have to be easy to measure, heritable and variable, and not too many (Hagos et al., 2018). Various methodological approaches have been used to identify breeding objectives of goats in Ethiopia, for instance, choice experiment method, ranking among a list of traits, and live animal rankings (Banerjee et al., 2000). Placing relevant breeding objectives, identifying indigenous breeding practices, and assigning relevant breeding objectives are crucial to the development of animal breeding programs (Tadele, 2010). However, programs will be successful when accompanied by a good understanding of the different farming/production systems, breeding objectives, and addressing several constraints (Baker and Gray, 2003).

Several studies have shown that goat keepers have developed their breeding practices which include a selection of bucks (Grum, 2010) or does (Tegegne, 2012) that are used either in controlled (Grum, 2010) or uncontrolled (Tesfaye et al., 2012) mating systems. Some studies, however, indicated an absence of selection in these approaches (Samuel, 2005; Tsedeke, 2007; Dereje, 2011) where selection is practiced, the criteria used are based on maternal (ancestral) history, production performance appraisal, and some other traditional systems. About $90.8 \%$ of Short-eared Somali goat keepers in Dire Dawa select their breeding stock based on maternal history (Grum, 2010; Feki, 2013). However, in the Central Rift Valley area both subjective and objective selection criteria are used with more emphasis placed on morphological traits of bucks (Tesfaye et al., 2012). Besides goat keepers in Ethiopia practice different traditional breeding practices which include a selection of bucks or does that are used either in controlled or uncontrolled mating systems (Getinet et al., 2016). These research findings indicated that the previous research studies lack the consistency of results. Also, there is limited information on breeding objectives and practices, trait preferences, and selection criteria of breeding stock used by owners of goats in southern parts of the Ethiopia especially in Abaya and Galan where indigenous breeds have special merit in the twinning type of birth. Consequently, this study was undertaken to identify breeding objectives, existing breeding practices, and selection criteria of goat owners in southern Oromia, Ethiopia.

\section{Research Methodology}

\section{Sample size, sampling techniques, and data collection}

The study was conducted in two districts of the pastoral areas, Abaya and Galan. For this study, site selection and the household baseline surveys were conducted from September 1 to the beginning of December 2019. The purposive sampling technique was applied to select the study districts based upon the production potential by consulting the agriculture and natural resource office of the zone. Similarly, nine kebele were selected from each sample district based upon the size of the goat population. Sample households from each kebele were selected randomly. 180 households ( 90 per district, 10 per kebele) were taken. Data such as flock structure, size of goat per household, breeding practices, desirable 
qualities or selection criteria's of both doe and buck, mating system, castration methods, reproductive performance and prolificacy of goat and purpose of keeping goat were collected through interview schedule. In addition, data were collected through focus group discussions which comprise 10-15 numbers of participants. The group was composed of extension workers, developmental agents (DAs), model farmers, and village leaders.

\section{Method of data analysis}

All data gathered during the study period were coded and recorded in Microsoft Excel 2007 and SPSS version 20. Descriptive statistics were used to describe the results as percentages for both districts. Microsoft Excel was used for ranking data in a selection of doe and buck for breeding. The ranking was expressed as an Index $=$ Sum of ( $3 x$ ranked first $+2 x$ ranked second $+1 \times$ ranked third $)$ given for an individual reason divided by the sum of ( $3 x$ ranked first $+2 x$ ranked second $+1 \times$ ranked third) for all reasons (Musa et al., 2006). Furthermore, the effective population size and inbreeding rate of the community was calculated by combining individual household. An estimate of the average change in percentage inbreeding was calculated with the following expression:-

$$
\Delta F=\frac{1}{2 N e}
$$

Where: - $\Delta F=$ Rate of change in inbreeding

$\mathrm{Ne}=4 \mathrm{Nm} \times \mathrm{Nf} / \mathrm{Nf}+\mathrm{Nm}$

( $\mathrm{Ne}=$ the effective population number

$\mathrm{Nm}=$ number of breedable male $\mathrm{Nf}=$ number of breedable females (Falconer and Mackay, 1996)

\section{Results And Discussion}

\section{Goat Flock Structure and Management}

Adopting a breeding program appropriate to the production system helps genetic improvement and reduces incompatibility of genotype with farmer breeding objectives and production system and production environment which aimed at improving preferred traits. In this study, breeding does comprise a dominant part of the flock followed by kids between 6 months to one year. The higher proportion of adult females than other age groups across both study areas indicates the practice of retaining females for breeding (Table 1). This is due to the fact that goat keepers in the pastoral production system possessed significantly large proportions of female goats for breeding and occasionally for milk consumption. This result is in line with the work of Solomon et al. (2010) the proportion of different classes of animals reflects the management decision of the producers which in turn is determined by their production objectives. The ratio of males to females in both districts at the age of fewer than six 
months was proportional. However, female proportions were higher than males at the age of greater than one year in both districts. This is because male goats were frequently sold whenever cash is needed and farmers did not prefer female goats for meat purposes. This finding was in agreement with the result of Grum (2010) in the Dire Dawa zone, Mahilet (2012) in Eastern Hararghe, and Tesfaye (2010) for the ArsiBale goat population, in which the proportion of females is higher than a male goat. However pastoral and agro-pastorals keep a higher proportion of females reflecting the owners' need for milk for long periods in the hot environment (Farm-Africa, 1996 and Alefe, 2014).

Farmers in the study area sell out young goats well-conditioned male goats to earn a better price. This trend of selling early maturing and having fast growth male goats may affect the improvement of the flock in consecutive generations. The ratio between males greater than one year of age and their female counterparts in Abaya and Galan districts was 1:3 and 1:2 respectively. This result is contradictory with that of Adugna (1998) who explains 1:4 in Kochore district, southern Ethiopia, and Wilson (1989) who explained the ratios 1:4 to 1:6 a standard for small ruminants in traditional livestock production systems of Africa. This was due to the study area holding a small number of goats per flock. In this study, a small number of breeding males and females may bring a high rate of inbreeding.

\begin{tabular}{|c|c|c|c|c|c|c|c|}
\hline \multirow{3}{*}{$\begin{array}{l}\text { Goat class by sex } \\
\text { and age }\end{array}$} & \multicolumn{7}{|l|}{ Districts } \\
\hline & \multicolumn{3}{|c|}{ Abaya $N(90)$} & \multicolumn{3}{|c|}{ Galan N(90) } & \multirow{2}{*}{$\begin{array}{l}\text { Overall } \\
\text { Mean } \pm \text { SE }\end{array}$} \\
\hline & Sum(n) & Mean $\pm S E$ & $\%$ & Sum(n) & Mean $\pm S E$ & $\%$ & \\
\hline$<6$-month male kids & 125 & $1.38 \pm 0.17$ & 15.43 & 68 & $0.76 \pm .09$ & 16.19 & $1.07 \pm 0.1$ \\
\hline $\begin{array}{l}<6 \text {-month female } \\
\text { kids }\end{array}$ & 147 & $1.63 \pm 0.18$ & 18.14 & 61 & $0.47 \pm .07$ & 14.52 & $1.05 \pm 0.1$ \\
\hline $\begin{array}{l}\text { Male } 0.5 \text { to } 1 \text { year } \\
\text { (Bucks) }\end{array}$ & 100 & $1.13 \pm 0.13$ & 12.34 & 43 & $0.72 \pm .06$ & 10.23 & $0.92 \pm 0.07$ \\
\hline $\begin{array}{l}\text { Female } 0.5 \text { to } 1 \text { year } \\
\text { (Does) }\end{array}$ & 127 & $1.49 \pm 0.19$ & 15.67 & 65 & $1.07 \pm 0.08$ & 15.47 & $1.28 \pm 0.1$ \\
\hline $\begin{array}{l}\text { Male>1 year } \\
\text { (Breeding buck) }\end{array}$ & 65 & $0.72 \pm .1$ & 8.02 & 66 & $0.73 \pm .09$ & 15.71 & $0.73 \pm 0.07$ \\
\hline $\begin{array}{l}\text { Female>1year } \\
\text { (Breeding does) }\end{array}$ & 211 & $2.34 \pm .33$ & 26.02 & 96 & $1.07 \pm .10$ & 22.85 & $1.71 \pm 0.17$ \\
\hline Castrated male & 35 & $0.39 \pm .09$ & 4.32 & 21 & $0.23 \pm .05$ & 5 & $0.31 \pm 0.05$ \\
\hline Total & 810 & $9 \pm 0.74$ & 100 & 420 & $4.69 \pm 0.23$ & 100 & \\
\hline
\end{tabular}




\section{Goat breeding practices}

The genetic improvement is cumulative and eventually leads goats to mature earlier in Galan than Abaya, which is indeed a directional/natural selection. Moreover, it is not uncommon that goat herders in different localities have their own trait preferences and selection criteria based on existing production environments, market demands, and other factors that lead to variation in selection criteria. For instance, Gebrekiros (2014) reported that farmers in Western Tigray prioritize the twining ability of goats over any other traits in Begait/Barka goats.

\section{Selection Criteria for Breeding Buck}

The selection criteria of breeding bucks are indicated in Table 2. The selection of stock for breeding purposes is a prerequisite to replace better stocks by considering its own morphological, adaptive, and production characteristics. In this study traits like conformation, growth rate, coat color, pedigree, and age were considered as important traits in selecting breeding buck. In Abaya district conformation/appearance, color (white and red), and growth rate of buck were ranked 1st, 2nd, and 3rd, respectively. The corresponding rankings for the Galan district were, conformation/appearance followed by the growth rate, color, and age of buck.

However, goat herders in both districts commonly focus on body conformation (long leg) to select breeding buck, which is indeed highly associated with genetic performances. This indicates that goat herders have their ways of ranking traits based on the purposes they keep. This result was in agreement with the finding of Belete (2013) who reported that farmers select their buck by considering appearance in the Bale zone which is similar production (crop-livestock) system with study area. Selecting buck by growth rate was more practiced in Galan than Abaya. This might be associated with the fact that Galan is a district known as a hub for growing cash crops, mainly coffee that created a market opportunity for goat herders in the areas to focus on the fast growth rate for better prices. 
Table 2

Ranking selection criteria of breeding buck

\begin{tabular}{|lllllllll|}
\hline Selection criteria & \multicolumn{1}{l}{ Abaya } & \multicolumn{7}{c|}{ Galan } \\
\hline & R1 & R2 & R3 & I & R1 & R2 & R3 & I \\
\hline Conformation & 78 & 7 & 2 & 0.46 & 74 & 7 & 1 & 0.44 \\
\hline Color & 0 & 39 & 26 & 0.19 & 4 & 10 & 22 & 0.10 \\
\hline Horn & 0 & 4 & 8 & 0.03 & 0 & 1 & 1 & 0.01 \\
\hline Character & 0 & 0 & 7 & 0.01 & 4 & 4 & 2 & 0.04 \\
\hline Adaptability & 0 & 0 & 2 & 0.00 & 0 & 3 & 11 & 0.03 \\
\hline Growth rate & 8 & 15 & 24 & 0.14 & 8 & 38 & 14 & 0.21 \\
\hline Age & 0 & 4 & 7 & 0.03 & 0 & 20 & 8 & 0.09 \\
\hline Libido & 0 & 3 & 0 & 0.01 & 0 & 4 & 16 & 0.04 \\
\hline Pedigree & 4 & 18 & 14 & 0.11 & 0 & 3 & 15 & 0.04 \\
\hline I= index and R= rank & & & & & & & \\
\hline
\end{tabular}

\section{Selection Criteria for Breeding Doe}

Selection criteria of breeding doe in the study area are presented in Table 3. According to the respondents' opinion, conformation/appearance is the main criteria for the selection of doe in both districts. However while twining ability ranked second in Abaya district, age at sexual maturity was given the second priority in Galan. 
Table 3

Ranking selection criteria for breeding doe

\begin{tabular}{|lllllllll|}
\hline Selection criteria & \multicolumn{3}{c}{ Abaya } & \multicolumn{7}{c|}{ Galan } \\
\cline { 2 - 9 } & R1 & R2 & R3 & I & R1 & R2 & R3 & I \\
\hline Conformation & 78 & 2 & 6 & 0.45 & 77 & 5 & 0 & 0.45 \\
\hline Color & 0 & 25 & 18 & 0.13 & 2 & 14 & 13 & 0.09 \\
\hline Kid growth & 0 & 0 & 9 & 0.02 & 0 & 8 & 23 & 0.07 \\
\hline Age at sexual maturity & 1 & 5 & 2 & 0.03 & 6 & 24 & 24 & 0.17 \\
\hline Kidding interval & 1 & 25 & 16 & 0.13 & 0 & 12 & 12 & 0.07 \\
\hline Twining ability & 10 & 25 & 15 & 0.18 & 4 & 26 & 13 & 0.14 \\
\hline High milk yield & 0 & 8 & 24 & 0.07 & 1 & 1 & 5 & 0.02 \\
\hline I= index and R= rank & & & & & & & & \\
\hline
\end{tabular}

\section{Mating and Castration}

The percentage of households who practiced buck castration and the method of castration used are presented in Table 4. The proportion of households who practiced castration and the average age of castration varied from place to place. As per the respondents, 79 and $74 \%$ practiced castration in Abaya and Galan districts, respectively. About two-thirds of respondents practiced the modern method of castration indicating that goat keepers in the study districts have access to local veterinary services. A similar result was reported by Mahilet (2012) in Eastern Hararghe. Indeed, this is a common practice by livestock keepers where the respondents indicated that castration is a value-adding process (fattening) in both districts to avoid weight loss due to mating that eventually benefits farmers earn better prices at marketing. Moreover, respondents argued that a castrated goat has fewer odors, produces tasty and tender meat than uncastrated goats. Almost all respondents in both districts report selecting the breeding buck for future generations. One of the drawbacks observed in both districts was that there was no controlled mating practice. This leads to a high inbreeding rate that eventually leads to population inbreeding depression (Maiwashe et al., 2006).

Table 4. Breeding practices of goat farmers 


\begin{tabular}{|c|c|c|c|c|c|c|}
\hline & \multicolumn{2}{|c|}{ Abaya N (\%) } & \multicolumn{2}{|c|}{ Galan N (\%) } & \multicolumn{2}{|c|}{ Overall N (\%) } \\
\hline & Yes & No & Yes & No & Yes & No \\
\hline $\begin{array}{l}\text { 1. Do you identify a sign of } \\
\text { heat? }\end{array}$ & $89(98.9)$ & $1(1.1)$ & $62(68.9)$ & $28(31.1)$ & 151(83.9) & $29(16.1)$ \\
\hline $\begin{array}{l}\text { 2. Do you allow others to } \\
\text { mate your doe? }\end{array}$ & $90(100)$ & - & $90(100)$ & - & $180(100)$ & - \\
\hline \multicolumn{7}{|l|}{ 3. Did buck mate his } \\
\hline \multirow{3}{*}{$\begin{array}{l}\text { - Mother } \\
\text { - Sib } \\
\text { - Progeny }\end{array}$} & $90(100)$ & - & $90(100)$ & - & 180(100) & - \\
\hline & $90(100)$ & - & $90(100)$ & - & $180(100)$ & - \\
\hline & $90(100)$ & - & $90(100)$ & - & $180(100)$ & - \\
\hline $\begin{array}{l}\text { 4. Do you select breeding } \\
\text { bucks? }\end{array}$ & $90(100)$ & - & $88(97.7)$ & $2(2.2)$ & 178(98.9) & $2(1.2)$ \\
\hline $\begin{array}{l}\text { 5. Do you practice castrate } \\
\text { buck? }\end{array}$ & 71(78.9) & 19(21.1) & $67(74.44)$ & $23(25.5)$ & 138(76.7) & 42(23.3) \\
\hline \multicolumn{7}{|l|}{$\begin{array}{l}\text { 6. Methods of castration } \\
\text { use }\end{array}$} \\
\hline - Modern & \multicolumn{2}{|l|}{$70(77.8)$} & \multicolumn{2}{|l|}{$59(65.6)$} & \multicolumn{2}{|l|}{$59(65.6)$} \\
\hline - Traditional & \multicolumn{2}{|l|}{$30(33.3)$} & \multicolumn{2}{|l|}{$31(34.4)$} & \multicolumn{2}{|l|}{$31(34.4)$} \\
\hline
\end{tabular}

$\mathrm{N}=$ number of household

\section{Effective Population Size and Rate of Inbreeding}

The effective population size $(\mathrm{Ne})$ and the rate of inbreeding $(\Delta \mathrm{F})$ calculated for goat flock in the study area are presented in Table 5. Effective population size is a measure of genetic variability within a population, with large values of Ne indicating more variability and small values indicating less genetic variability. In this study, the estimate of effective population size ( $\mathrm{Ne})$ was 2.2 and 1.73 in Abaya and Galan districts, respectively. The rate of inbreeding in the study area is beyond the threshold level or maximum acceptable level (0.063) Armstrong (2006). This was due to small effective population size, utilization of breeding buck born within the flock, and uncontrolled mating. This finding is comparable to that of Tesfaye (2010) who report the inbreeding coefficient of Afar sheep in Ethiopia (0.20) and Belete (2013) who reported 0.21 from a Bale goat population.

Table 5. The inbreeding rate and effective population size 


\begin{tabular}{|ccccc|}
\hline District & \multicolumn{4}{c|}{ When flock are not mixed } \\
& $\mathrm{Nm}$ & $\mathrm{Nf}$ & $\mathrm{Ne}$ & $\Delta \mathrm{F}$ \\
\hline Abaya & 0.72 & 2.32 & 2.2 & 0.22 \\
\hline Galan & 0.73 & 1.07 & 1.73 & 0.29 \\
\hline
\end{tabular}

\section{Measures of Reproductive Performance}

The reproductive performance of the goat in the study area is summarized in Table 6 . The overall mean reproductive lifetime of the female goat was $7.2 \pm .12$ years within this year a doe could produce around $12.1 \pm .22$ kids. Age at first kidding (AFK) can be defined as the age at which does give birth for the first time. The overall Age at first kidding (AFK) of goats in the study area was $12.11 \pm .40$ months. This is in agreement with the study of Alefe (2014) who reported AFK of indigenous goats in the Shabelle zone, Ethiopia was about 14.75 months, and Gebrekiros (2014) who reported AFK of 12-18 months for Begait goats. However, Adugna (1998) reported AFK of 19.5 months for Kochore goats in SNNP. Age at first kidding in Ethiopian breeds is a well-known trait at the farm level and it ranges from 12-24 months (Girma, 2008). Age at first kidding is highly variable and dependent on the growth rate and management practices (Song and Sol, 2006).

The overall average kidding interval $(\mathrm{KI})$ in months for Abaya and Galan goats was 7.83 \pm .13. This is contradictory with a report of Mahilet (2012) who reported a kidding interval of $6.56 \pm .04$ months for Eastern Hararghe goats. According to studies of Belete (2013); Alefe (2014) and Tesfaye et al. (2012) KI interval ranges from 8-11.7 months for different breeds of goats in Ethiopia. Moreover, poor nutrition and prolonged suckling resulted in the longer interval between kidding. The overall reproductive lifetime of male goats was also $4.5 \pm 0.77$ years which is shorter than their female counterparts. This is mainly due to the fact that, except bucks used for breeding, most males are castrated and do not stay long in the flock as they were sold. This result is disagreeing with other previous studies such as Belete (2013) and Alefe (2014) who reported that the reproductive life span of the buck was 8.6 and 6.5 years in Bale and Shabelle zones, respectively.

Table 6. Reproductive parameters of sampled goats 


\begin{tabular}{|llll|}
\hline Reproductive trait & Abaya & Galan & Overall \\
\hline & Mean + SE & Mean + SE & Mean + SE \\
\hline Average age at first kidding (months) & $11.99 \pm .612$ & $12.17 \pm .248$ & $12.11 \pm .398$ \\
\hline Average kidding interval (months) & $7.62 \pm .122$ & $8.04 \pm .243$ & $7.83 \pm .136$ \\
\hline The average reproductive life span of doe (years) & $7.58 \pm .167$ & $6.74 \pm .170$ & $7.16 \pm .123$ \\
\hline Average servicing age of buck in a flock (years) & $4.37 \pm .127$ & $4.6 \pm .087$ & $4.5 \pm .077$ \\
\hline The average number of kid crops per doe (Number) & $12.02 \pm .381$ & $12.20 \pm .221$ & $12.11 \pm .220$ \\
\hline
\end{tabular}

\section{Prolificacy of Goat}

The prolificacy of the goat in the study area is summarized in Table 7. Based on the respondent's opinion, a higher twinning rate of about $72.2 \%$ was reported, with only $26.66 \%$ single births. This implies that the goat population in the study area is highly prolific and warrants closer attention for selection. This result is disagreeing with the similar production system study of Mahilet (2012) who describes single birth as highly predominant in Eastern Hararghe goats. Also, the present result is significantly higher than the twining rate report of Woito Guji goats, which was only 16\%, and Arsi Bale goats breeds (18\%) (FarmAfrica, 1996).

Table 7. Prolificacy of goat

\begin{tabular}{|lllllll|}
\hline Types of birth & \multicolumn{2}{l}{ Abaya } & \multicolumn{2}{l}{ Galan } & \multicolumn{2}{l|}{ Overall } \\
& N & $\%$ & N & $\%$ & N & $\%$ \\
\hline Single & 28 & 31.11 & 20 & 22.22 & 48 & 26.66 \\
\hline Twins & 61 & 67.78 & 69 & 76.66 & 130 & 72.22 \\
\hline Triplets & 1 & 1.11 & 1 & 1.11 & 2 & 1.11 \\
\hline
\end{tabular}

\section{The purpose for Keeping Goats}

The purpose of keeping a goat in the study area is shown in Table 8. The main purpose of keeping a goat in Abaya was mentioned as sources of income, insurance risk (live asset), and meat consumption whereas sources of income, meat, and saving are primary purposes in Galan. Traditionally, goat keepers 
in the study district believe that eating goat meat and its by-product (blood, brain, and small intestine) have some medicinal values. Milk is consumed by goats in both districts. This finding was disagree with the result of Ahmed et al. (2015) who reported that milking was not accustomed by the community of Horro Guduru district of Wolega zone. like in the case of some pastoral communities (pastoral and agropastoral production system) in Ethiopia, goat milk is consumed. The utilization of goat manure as soil fertilizer is higher in Galan than in Abaya indicating that farmers in Galan practice crop cultivation as their supplementary farm activities as compared to the pastoral system practiced in Abaya.

Goat milk is consumed in both districts, indeed milking goat is a common practice in the pastoral and agro-pastoral production systems. Group discussants in districts believed that goat milk has medicinal value for children against ascarids. Moreover, it was reported that goat milk increases the appetites of the children. It was reported that specifically goat blood is given to women immediately after birth to cure lesions and overcome anemia due to heavy blood loss.

Table 8. Purpose of keeping a goat

\begin{tabular}{|llllllllll|}
\hline Purpose & \multicolumn{1}{l}{ Abaya } & \multicolumn{7}{l}{ Galan } \\
& R1 & R2 & R3 & I & R1 & R2 & R3 & I \\
\hline Meat & 12 & 18 & 30 & 0.19 & 8 & 27 & 30 & 0.20 \\
\hline Milk & 3 & 10 & 11 & 0.07 & 0 & 2 & 0 & 0.01 \\
\hline Feels for hats and mattresses & 1 & 1 & 0 & 0.01 & 7 & 3 & 0 & 0.05 \\
\hline Sale (cash income) & 31 & 31 & 16 & 0.32 & 55 & 17 & 3 & 0.37 \\
\hline Insurance for risk & 27 & 24 & 10 & 0.26 & 1 & 0 & 12 & 0.03 \\
\hline Ceremonies(gift/wedding, sacrifices) & 1 & 0 & 2 & 0.01 & 0 & 0 & 0 & 0.00 \\
\hline Prestige and socio-culture value & 1 & 1 & 1 & 0.01 & 5 & 2 & 2 & 0.04 \\
\hline Savings & 4 & 3 & 7 & 0.05 & 10 & 18 & 31 & 0.18 \\
\hline Collateral(for loan, compensation) & 1 & 0 & 6 & 0.02 & 0 & 0 & 0 & 0.00 \\
\hline Dowry & 0 & 1 & 0 & 0.00 & 0 & 0 & 0 & 0.00 \\
\hline rituals & 2 & 1 & 1 & 0.02 & 0 & 0 & 0 & 0.00 \\
\hline Manure as fertilizer & 2 & 0 & 6 & 0.02 & 0 & 16 & 12 & 0.08 \\
\hline Skin for home use & 5 & 0 & 0 & 0.03 & 4 & 5 & 0 & 0.04 \\
\hline
\end{tabular}

\section{Conclusion And Recommendation}

Farmers preferred many traits like Conformation, growth rate, coat color for buck and conformation, twining ability, age at sexual maturity, kidding interval, and color for females as selection criteria for 
replacing their stock. Moreover, conformation is a hub or primary selection criteria for both sexes of goat flock. Adopting a breeding program (community-based) that suited to this area which aimed at improving preferred traits is relevant.

\section{Declarations}

\section{Acknowledgments}

We thank your ministry of education of Ethiopia and district and kebele experts for their unlimited support

\section{Authors' contributions}

Teshager Muluneh participated in designing all research and wrote the manuscript. Wondim Awoke conducted data analysis and comments. All authors read and approved the manuscript.

\section{Funding}

This work was supported by the National ministry of education for staff development

\section{Availability of data and materials}

Data were available in the hands of Corresponding Author

\section{Ethics approval and consent to participate}

The manuscript does not contain clinical studies or patient animals

\section{Consent for publication}

Not applicable.

\section{Competing interests}

The authors declare that there is no conflict of interest involved in this study.

\section{References}

1. Adane H, Girma A (2008) Economic significance of sheep and goats. In Alemu Yami and R.C. Markel (eds). Sheep and goat Production handbook for Ethiopia. ESGPIP (Ethiopia Sheep and Goats Productivity Improvement Program), Addis Ababa, Ethiopia.

2. Adugna T (1998) Production Situation and Some Productivity and physical Characters of Traditionally Managed Sheep and Goats in Kochore district, Southern Ethiopia. Journal of Applied Animal Research, 13(2), 49-59. 
3. Ahmed S, Kefelegne K, Kefena E (2015) Breeding Objective, Selection Criteria and Breeding Practice of Indigenous goats in Western Ethiopia: implications For Sustainable Genetic Improvement. Greener Journal of Agricultural Sciences,5(5):167-176.

4. Alefe T (2014) Phenotypic characterization of indigenous goat types and their production system in Shabelle zone, southeastern Ethiopia. M.Sc Thesis Haramaya University, Haramaya, Ethiopia

5. Armstrong J B (2006) Inbreeding: Why we will not do it? http://www.parispoodles.com/Inbreed

6. Baker R L, Gray G D (2003) Appropriate breeds and breeding schemes for sheep and goats in the tropics: The importance of characterization and utilizing disease resistance adaptation to tropical stress

7. Banerjee A K, G. Animut, E. Ermias (2000) Selection and breeding strategies for increased productivity of goats in Ethiopia. In: R.C. Merkel, G. Abebe and A.L. Goetsch (eds.). The Opportunities and Challenges of Enhancing Goat Production in East Africa. Proceedings of a conference held at Debub University, Awassa, Ethiopia from November 10 to 12, 2000. E (Kika) de la Garza Institute for Goat Research, Langston University, Langston, OK pp. 70-79.

8. Belete A, Kefelegn K, Kefena E (2015) Breeding Objectives, Selection Criteria, and Breeding System of indigenous Goat type in Bale zone, Oromia, Ethiopia. International Journal of Agricultural Research Innovation and Technology, 5(2): 7-15, 2015, http://www.ijarit.webs.com

9. Belete A (2013) On-farm phenotypic characterization of indigenous goat types and their production system in bale zone of Oromiya region, Ethiopia. M.Sc Thesis Haramaya

10. CSA (2017) Federal Democratic Republic of Ethiopia, Central Statistical Agency, and Agricultural sample Survey 2016/2017, Volume 2, Livestock and Livestock Characteristics, Addis Ababa, Ethiopia.

11. Dereje T, Berhanu B, Aynalem H (2013) Linear Body Measurements as Predictor of Body Weight in Hararghe Highland Goats under Farmers Environment: Ethiopia, Global Veterinaria 11 (5):649-656, 2013.

12. Dereje T (2011) Herd husbandry and breeding practices of goat in different agro-ecologies of Western Hararghe, Ethiopia. MSc thesis. Jimma, Ethiopia: Jimma University

13. Falconer D, Mackay T (1996) Introduction to quantitative genetics 4th ed, Harlow, England, Longman.

14. Farm-Africa (1996) Goat types of Ethiopia and Eritrea.Physical description and management systems. Published jointly by FARM-Africa, London, UK, and ILRI (International Livestock Research Institute), Nairobi, Kenya.

15. Feki M (2013) Community-based characterization of Afar goat breeds around Aysaita district of Afar region. MSc thesis. Jimma, Ethiopia: Jimma University.

16. Gebrekiros H (2014) On-Farm Phenotypic Characterization of Begait (Barka) Goats and their Production System in the Western zone of Tigray, Ethiopia; MSc. Thesis Haramaya University, Haramaya, Ethiopia.

17. Gebreyesus A, Haile, T. Dessie (2012) Participatory characterization of the Short-eared Somali goat and its production environment around Dire Dawa, Ethiopia. Livestock Research for Rural 
Development. Volume 24, Article \#184.

18. Gemeda D (2010) Participatory definition of breeding objectives and implementation of communitybased sheep breeding programs in Ethiopia, Doctoral Thesis, University of Natural Resources and Life Sciences, Vienna.

19. Getinet M, Solomon G, Azage T (2016) Genetic-phenotypic and

20. production-system diversity in goat populations in Ethiopia: Options for sustainable production. lives Working Paper 22. Nairobi, Kenya: International Livestock Research Institute (ILRI).

21. Girma A (2008) Reproduction in sheep and goats. pp 57-77. In: Alemu Yami and R.C. Merkel (eds.). Sheep and goat production handbook for Ethiopia. Ethiopian sheep and goat productivity improvement program, USAID.

22. Grum G (2010) Community-based participatory characterization of the short-eared Somali goat population around Dire Dawa.MSc Thesis Haramaya University, Haramaya, Ethiopia.

23. Hagos A, Solomon G, Mengistu U (2018) Identification of breeding objectives for Begait Goat in Western Tigray, North Ethiopia. Tropical Animal Health and Production (2018) 50: 1887 - 1892.

24. Kosgey and Isaac S (2004) Breeding objectives and breeding strategies for small ruminants in the tropics. Ph.D. Thesis, Animal Breeding and Genetics Group, Wageningen University, With referenceWith summary in English and Dutch. ISBN: 90-5808-990-8

25. Kosgey I S, Rowlands G J, Van Arendonk J A M, Baker R L (2008) Small ruminant production in smallholder and pastoral/extensive farming systems in Kenya. Kenya Nairobi, Small Ruminant Research, 77(1), 11-24.

26. Mahilet $D$ (2012) Characterization of hararghe highland goat and their production system in eastern hararghe.MSc. Thesis Haramaya University, Haramaya, Ethiopia.

27. Maiwashe A, Nephawe K, Van der Westhuizen R, Mostert B, Theron H (2006) Rate of inbreeding and effective population size in four major South African dairy cattle breeds. South African Journal of Animal Science, 36 (1),50-57

28. Mekasha G, Isaac $S$ (2004) Breeding objectives and breeding strategies for small ruminants in the tropics. Ph.D. Thesis, Animal Breeding and Genetics Group, Wageningen University, With referenceWith summary in English and Dutch. ISBN: 90-5808-990-8

29. Musa L, Ahmed M, Peters K (2006) On-farm characterization of Butana and Kenana cattle breed production in Sudan. Livestock Research for Rural Development. 18 (12), 56-61.

30. Nandolo W, Maria W, Gábor M, Curt V, Timothy G, Henry M, Doreen L, Johann S (2016) Identification of Breeding Objectives in Community-Based Goat Breeding Programmes in Malawi, $24^{\text {th }}$ International Symposium. "Animal Science Days", Ptuj, Slovenia, Sept. 21 ${ }^{\text {st }}-23^{\text {rd }}, 2016$.

31. Samuel M (2005) Characterization of livestock production system potential, constraints and intervention strategies: A case study of Yerer watershed, Ada Liben district of East Showa, Ethiopia. MSc thesis. Dire Dawa, Ethiopia: Alemaya University 
32. Solomon G, Azage T, Berhanu G, Dirk H (2010) Sheep and goat production and marketing systems in Ethiopia: Characteristics and strategies for improvement. IPMS (Improving Productivity and Market Success) of Ethiopian Farmers Project Working Paper 23. ILRI (International Livestock Research Institute), Nairobi, Kenya. pp58.

33. Song $\mathrm{H}$, Sol $\mathrm{H}$ (2006) Reproductive performance of Korean native goats under natural and intensive conditions. Small Ruminant Research, 3(65), 284-287.

34. Tadele M (2010) Identifying breeding objectives of smallholders/pastoralists and optimizing community-based breeding programs for adopted sheep breeds in Ethiopia, Doctoral Thesis, University of Natural Resources and Life Sciences, Vienna.

35. Tegegne F (2012) On-farm phenotypic characterization of goat genetic resources in Bench Maji zone, southwestern Ethiopia. MSc thesis. Bahir Dar, Ethiopia: Bahir Dar University.

36. Tesfaye K, Aynalem H, Hailu D, Tesfaye A (2012) Genetic and

37. phenotypic parameter estimates for reproduction traits in indigenous Arsi-Bale goats.

38. Tropical Animal Health and Production, 44(5):1007-1015.

39. Tesfaye K (2010) Assessment of on-farm Breeding Practices and Estimation of Genetic and Phenotypic Parameters for Reproductive and Survival Traits in Indigenous Arsi Bale Goats. MSc Thesis Haramaya University, Haramaya, Ethiopia.

40. Tsedeke K (2007) Production and marketing systems of sheep and goats in Alaba, southern Ethiopia. MSc thesis. Awassa, Ethiopia: Hawassa University.

41. Wilson R (1989) Reproduction performance of African indigenous small ruminants under various management systems. Animal Reproduction Science, 20(4), 265-286. 